\title{
Cutting Porter's Last Diamond: Competitive and Comparative (Dis)advantages in the Dutch Flower Cluster
}

\author{
Ernesto Tavoletti $\cdot$ Robbin te Velde
}

Received: 14 March 2008/Accepted: 13 April 2008/Published online: 10 July 2008

(C) Springer-Verlag 2008

\begin{abstract}
The Dutch are the world's leaders in the flower business even though they seem to lack comparative advantage in the traditional sense. Comparative advantages played a role in the history of the Dutch flower cluster and they still have a role today. Based on a critic of Porter's theories, the investigation suggests that the exploitation of comparative advantages is allowed only to those firms and clusters that already possess a competitive advantage, based on technology, logistics infrastructure, innovation and human skills. So that comparative advantages and competitive advantages join in a sort of helix process based on social innovation and collective learning.
\end{abstract}

Keywords Dutch flower cluster - Comparative advantages ·

Competitive advantages · District · Innovation · Cluster

JEL Classification Q17 · M16 - L26

\section{Introduction}

The present article is an exploratory case study of the Dutch flower cluster and it is intended to forecast opportunities and threats for its future. The Dutch flower cluster has gone through significant success for decades but recent development in the international markets has raised questions about its competitiveness and environ-

\footnotetext{
E. Tavoletti $(\bowtie)$

University of Macerata, Macerata, Italy

e-mail: ernesto.tavoletti@unimc.it

R. te Velde

Dialogic Innovation and Interaction, The Hague, The Netherlands

e-mail: tevelde@dialogic.nl
} 
mental sustainability. Is the Dutch flower cluster going to survive the competition from developing countries with cheap labour, superior climate and increasing long distance distribution? Is there a future in a global economy for the over regulated Dutch flower cluster based on family SMEs and greenhouses?

Our research questions have a general theoretical interest in the cluster literature because agriculture clusters are potentially the more affected by superior Ricardian comparative advantages in developing countries. As the Dutch flower cluster is a very high-tech and knowledge intensive one, this makes the issue even more relevant: Can the socially driven knowledge exchanges (Storper 1993, 1995, 1997) and long lasting "social fabric" rival developing countries advantages on production factors?

Porter is the most cited scholar with reference to clusters' competitive advantage and he defines a cluster as "a geographically proximate group of interconnected companies and associated institutions in a particular field linked by commonalities and complementarities" (Porter 2000, p.16) with a strong focus on constituent firms and no significant reference to the cluster "social and territorial" knowledge while the most recent literature about cluster competitive advantage shifted from the cluster and its constituent firms to the character of the organizational knowledge within the cluster (Tallman et al. 2004; Asheim et al. 2006).

Developing countries' strong performance has introduced some doubts into the general view. Are comparative advantages based on cheap labour and superior climate taking "historical revenge", as opposed to Porter's competitive advantages and "knowledge based clusters" (Cooke and Leydesdorff 2006)? The article investigates this theoretical issue through the Dutch flower cluster.

"Theoretical framework and methodology" presents our theoretical framework and methodology: starting from a critic of Porter's competitive advantage approach, we introduce a new theoretical framework based on a revaluation of comparative advantages and their dynamic historical relationship with competitive advantages. "The Dutch flower cluster" provides an overview of the Dutch flower cluster. "Comparative (dis)advantages" analyses the cluster comparative advantages and "Competitive advantages" focuses on competitive advantages. "Explaining the success of the Westland region" attempts an explanation of the Dutch flower cluster success, through a micro and meso level analysis, paying special attention to logistics as an important "value adding activity". "A synthesis of Dutch case" draws a synthesis and a conclusion about the Dutch case, based on the theoretical framework developed in "The Dutch flower cluster".

\section{Theoretical Framework and Methodology}

The article is based on secondary data sources and a field visit that both the authors had in April 2005. In the course of the field visit the authors had the opportunity to hold a number of open-ended interviews with Dutch producers and dealers. The present article is the final report of our case study research about the Dutch flower cluster. 
Based on Porter's work (Porter 1990a, b, 1998, Porter and van der Linde 1995), we considered the following question: How can the Dutch be the world's leaders in the flower business when they lack comparative advantage in the traditional sense? Porter's answer, among other reasons, is that they have innovated at every step in the value chain, creating technology and highly specialized inputs that enhance resource productivity and offset the country's natural disadvantages. While we agree with Porter as far as the role of technology and innovation are concerned in order to explain competitive advantage, we also stress the importance that comparative advantages had in the development of the cluster and highlight that comparative advantages still have a major role in the cluster delocalisation trends.

It has already been suggested that Porter's framework has "fundamental misunderstandings of the factors that determine trade, particularly with respect to the principle of comparative advantage. [..] Sustained prosperity may be achieved without a nation becoming innovation-driven" (Davies and Ellis 2000, p. 1189). Porter's central claim was, in fact, the assertion that a "new paradigm" was created by replacing the outdated concept of comparative advantage with the more dynamic concept of "competitive advantage". Porter's devaluation of the importance of comparative costs is not supported by the Dutch flower cluster history or by its current trends.

In addition, within Porter's framework, activities are viewed in terms of hostile relations between economic actors. He considers collaboration as a potential source of erosion to long-term competitive advantage (Porter 2001). On the opposite, our study suggest that collaboration and cooperation can lead to strengthening social conditions, both at the inter-corporate and community levels, and ultimately produce continuous increase of the market share" (Aktouf et al. 2005; Moore 1996). The validity of Porter's contribution to the discourse on competitive advantage is reaffirmed but its theory is weakened by its neglect of cultural factors, historical antecedents, the role of government (O'Shaughnessy 1996) and the still important comparative advantages of nations.

Our exploratory investigation suggests that the exploitation (at home through service providing and abroad through delocalisation) of comparative advantages in new markets abroad is still important and is allowed only to those firms and industries that already possess a competitive advantage in the international arena, based on technology, logistics infrastructure, innovation and human skills. So that comparative advantages and competitive advantages join themselves in a sort of helix process, where each of them comes back to be dominant from time to time but at a superior level that takes advantage of previous gains on both front.

The main lesson is that regional strategies which are purely based on local comparative advantages (such as "typicality" and access to niche markets) are not a good option, unless it is reinforced by a clear competitive advantage strategy. Such a strategy should be innovation and technology based, able to exploit these comparative advantages and simultaneously able to exploit comparative advantages abroad, wherever they are. 


\section{The Dutch Flower Cluster}

The Dutch flower cluster is concentrated in two areas in the densely populated western part of The Netherlands, a northern part close to Amsterdam and a southern part close to Rotterdam. Historically the southern region ('Westland') specialised in vegetables. Due to increasing global competition at the end of the 1970s the production shifted to (the less commodified) flowers. In both regions the flower auction plays a pivotal role in the economic activities. Aalsmeer (north) and Naaldwijk (south) are by far the biggest flower auctions in the world. They are also competing.

Despite the modest size of the regions the economic performance is impressive. On a national scale, the greenhouse cluster at large accounts for about $2 \%$ of GDP. ${ }^{1}$ The export value of cut flowers in 2003 was 3 billion Euro and represented over $80 \%$ of the EU export. ${ }^{2}$ Nearly $95 \%$ of all flowers in the world are traded at the auctions of Aalsmeer and Naaldwijk ('Flora Holland'). These figures are all the more astonishing given the fact the Netherlands are neither endowed with a favourable climate ${ }^{3}$ not with an abundance of land. ${ }^{4}$ The obvious question is of course how the Dutch can be the world's leaders in the flower business when they lack comparative advantages in the traditional sense? According to Porter and van der Linde (1995) this is because they have innovated at every step in the value chain, creating technology and highly specialised inputs that enhance resource productivity and offset the country's natural disadvantages. This is certainly the case, and we will further elaborate the thesis. However, the technological argument is just a partial explanation of the success of the Dutch flower cluster. There are also other issues at stake.

\section{Comparative (Dis)advantages}

First of all, with regard to the factor conditions, the comparative position of the Netherlands is not as disadvantageous as it might seem. Although today there is certainly a lack of space (especially in the Westland region) in earlier days the land along the coast was sparsely populated. The rich loamy soil behind the sand dunes is particularly suitable for growing flowers. The temperate climate is a blessing in disguise considering the fact that the growth of flowers is especially negatively

\footnotetext{
${ }^{1}$ About 4.5 billion Euro (1998). Source: De Groot (2001).

2 The share in fresh cut flowers comes close to $90 \%$. This could be taken as an indicator for the relative efficiency of the Dutch logistics system since the characteristics of fresh cut flowers (extremely short longevity and delicacy) demands very fast yet careful transportation and handling.

${ }^{3}$ The Netherlands has a temperate maritime climate. Average temperatures range from 2 to $17^{\circ} \mathrm{C}$.

${ }^{4}$ The Netherlands is one of the most densely populated countries in the world - and within the country, most people live in the western part: Holland. The string of big cities along the coastal shore is called "Randstad". In the province of Zuidholland (where the Westland region is situated) the density figure is 1,000 people per square $\mathrm{km}$. For the sake of comparison, comparable figures are only found in Bangladesh. The average figure for Italy is 195 .
} 
Table 1 Main export countries for cut flowers (world export percentage)

Source: UNSO ITC Comtrade database

\begin{tabular}{llcc}
\hline & 1991 & 1994 & Change (\%) \\
\hline Netherlands & 64 & 56.5 & -13 \\
Colombia & 11.5 & 14.1 & 18 \\
Israel & 4.3 & 4.2 & -2 \\
Kenya & 1.6 & 2.7 & 41 \\
Ecuador & 0.6 & 2.7 & 78 \\
Italy & 3.3 & 2.4 & -38 \\
Thailand & 2.2 & 2.1 & -5 \\
Spain & 2 & 1.6 & -25 \\
Zimbawe & 0.4 & 1.3 & 69 \\
\hline
\end{tabular}

effected by warm (over $25^{\circ} \mathrm{C}$ ) and cold temperatures. The Dutch growers were early adopters of greenhouse technology. ${ }^{5}$ Due to the availability of huge reserves of natural gas-a genuine natural advantage of the Netherlands indeedproduction costs of vegetables and flowers could be kept relatively low. Secondly, due to the presence of many waterways big cities such as Amsterdam, Rotterdam and The Hague were within easy reach of the regions. Thus there was a readily available market for fresh vegetables and flowers-demand conditions were favourable.

In other words the comparative point of departure for the Netherlands was not bad at all. However, more recently competition from countries with a warmer climate and more land (vegetables from Mediterranean countries, roses from Africa) has put considerable pressure on the competitive position of the Dutch growers (see the explosive growth of the share in world export of Kenia and Zambabwe, Table 1). With regard to the land issue, the regional and national government have an official policy to relocate nurseries to less populated areas outside the Randstad. However, growers are reluctant to move because speed is everything in the flower cluster. It is regarded of vital importance to be at striking distance within suppliers and customers-and all are located in the closely knit regional district of the Westland. The ever-present traffic congestion in the Randstad is a formidable challenge to the region. At the same time it makes relocation outside the Randstad even less attractive because it just takes too much time to enter the Westland. With regard to the climate issue, the strict Dutch environmental regulation puts considerable pressure on the energy-intensive production style of the Dutch nurseries. ${ }^{6}$ Government subsidies for natural gas are gradually faded out, thus the comparative advantage of cheap energy vis-a-vis competing countries is eroding.

\footnotetext{
5 At the end of the nineteenth century the Westland region was already known for its grapes. These were produced using sun lounges that were imported from Belgium.

6 The horticulture industry is one of the major producers of $\mathrm{CO}_{2}$ in the Netherlands.
} 


\section{Competitive Advantages}

According to Porter (1990a, b, 1998), in the long run, the success of an industrial district is determined by its competitive advantages. The difficult process of acquiring competitive advantages, however, always occurs against the backdrop of the comparative advantages. In most cases of industrial development we studied technology was being used to compensate for natural disadvantages. ${ }^{7}$ In the case of the Westland, the comparative advantages (rich loamy soil, temperate maritime climate, waterways to big cities) initially formed a protected niche for the enfant cluster. The remarkable resilience of the region can however, be entirely attributed to its specific socio-technical fabric - which is its core competitive advantage. ${ }^{8}$ For more than 100 years the region has been able to fend off all threats, natural and man-made disasters and use the newly acquired abilities as a competitive advantage during later stages.

The Westland industrial cluster then seems to be able to constantly re-invent itself. In response to the 1870-1880 economic crisis a quality institute avant la lettre was established to collectively improve the quality of the production methods of the cluster as a whole. Ultimately this led to the introduction of the auction system in the early twentieth century and the establishment of cooperative banks and cooperations for horticulture requisites. ${ }^{9}$ These social inventions lead to an enormous growth of the export of vegetables. ${ }^{10}$ The world economic crisis of the 1930s had disastrous impacts on the region and the subsequent events during WWII brought the region to the verge of collapse. Because of its strategic location just behind the coastal defence works the German occupiers removed all greenhouses in the Westland and inundated large parts of the area. It took the region several years to recover but in the 1950s the export of vegetables (ironically mostly to Germany) and now also flowers, started to take off again - this time with an entirely new technological infrastructure.

\footnotetext{
${ }^{7}$ In Porter's jargon, 'selective factor disadvantage' may have a stimulating effect on (technological) innovation (Porter 1998, pp. 78-82). Examples at the national level are Canada and Australia that due to there extensiveness are frontrunners in distant applications (e-Education, e-Health). At the regional level, the wireless technology/satellite cluster around Calgary originates in the combination of remote sites (mining industry) connected to a central office and rugged landscape which prohibits to use of conventional land-based communication technology (Langford et al. 2003). The argument is also connected to demand conditions (1998, p. 87): industries will have an advantage in market segments which are more important at home than elsewhere (compulsory education and health care in remote areas in Canada and Australia, serving the communication needs of remote mining plants in the Calgary region). Also compare the remarkable evolution from the Finnish firm Nokia from a wood processing firm into a world leader in mobile telecommunications (Häikiö 2002).

${ }^{8}$ The contrast with competing regions with more favourable natural conditions is striking in this respect. The Italian flower districts, for instance, which started to make serious inroads in European exports, are still recovering from the severe cold which hit them in 1987. History has recently repeated in Spain.

${ }^{9}$ It took the institute, "Westland Vereeniging", over 30 years to bring all growers under the collective auction system. Ultimately, the state of emergency during WWI (during which the Netherlands remained neutral) was used to force the resistant growers to use the auction system (by making participation to the auction association compulsory for the submission of an export permit).

${ }^{10}$ Especially tomatoes and cucumbers for the German market. This has remained an important market up until today.
} 
During the 1960s and 1970s the cluster base was further strengthened. The shift from vegetables to flowers continued. Most nurseries switched to greenhouses which were initially heated by oil and later by natural gas. Consolidation occurred in the supporting auction infrastructure. Ultimately only two big auctions remained. During all those years the flower cluster saw a double digit growth and the export market now embraced the entire world. After the oil crisis at the end of the 1970s the price for natural gas rose sharply. At about the same time the environment became an important political issue and regulation of the agriculture industry as a whole was tightened. Once again the challenge turned out to be blessing in disguise. Ultimately it compelled the cluster to introduce a string of technological innovations that significantly increased yields and lowered production costs per unit.

After the early 1990s the era of eternal growth came to a halt. For the first time supply was bigger than demand. The margins came under pressure and at the micro level the obvious way out was to scale up production. Small family businesses were bought up by bigger ones. The strategy of the local banks, which is closely intertwined with the flower business, was to support the ever-bigger start-ups. Small enterprises were no longer backed up because assumingly they could not afford the expensive technological rat race any more. At about the same time flower export from Africa starts to make serious inroads in the European market (Table 1). Initially these flowers were all still traded via the two auctions in The Netherlands. Later on the 'African' flower exporters set up their own auction close to Aalsmeer (TFA). ${ }^{11}$ A growing part of the export is also directly sold to end users (e.g., from Zimbabwe to supermarket chains in the UK). At the turn of the millennium, then, the Westland seems to be under serious threat again. The technological superiority of the Dutch nurseries is no longer able to offset the difference in comparative advantages with tropical countries. ${ }^{12}$ The region itself is choking in traffic congestion and relocation does not really seem to be an option. The holier-than-thou attitude of the Dutch government with regard to environmental regulation leads to unfair competition within the EU. ${ }^{13}$ Meanwhile the reversal from a demand to a supply driven market erodes the unique collaborative culture of the region. The continuing increases in scale leave little space for small family businesses (Table 2). The shrinking margins put pressure on the traditional cultural openness of the

\footnotetext{
11 Most growers in Kenia and Africa are Dutch emigrants. The same goes for Brazil which has a Dutch enclave specialised in producing seedlings (for the Dutch market). The share of imports from Africa is constant (about 68\%) but the overall volume of import is sharply rising.

12 The African nurseries are big competitors in the literal sense. One of the nurseries in Kenia has 200 ha of roses (average size in The Netherlands is about $1 \mathrm{ha}$ ). About $50 \%$ is traded via (the Dutch) auctions (used to be $100 \%$ ). The other $50 \%$ is directly to wholesale and retail trade (roses are already pre-packaged in the wrapping of the super market chain) using the own logistical infrastructure of the firm. The firm has its own airplanes.

13 The strict observance of official international environmental regulation would in theory be beneficial to the Dutch growers since they can easily meet the standards whereas many of their competitors cannot; for example MPS (which is a Dutch collection of labels in various classifications-MPS A, B, Cproviding information on the social, environmental or quality aspects of a product in the flower sector) requires fully automated processes. In practice most other countries are rather lenient and as a consequence the green hallmarks do not function as a filter for quality. Instead these hallmarks are being used by wholesale traders to force down market prices-which has little or nothing to do with the environment anymore.
} 
Table 2 Percentage of family workers in each industry in 2002 (in brackets the decrease recorded over 2000-2002)

Source: http://www.tuinbouw. nl/website/ptcontent.nsf/home

\begin{tabular}{lll}
\hline & $2002(\%)$ & Change \\
\hline Flowers under glass & 21 & $(-22 \%)$ \\
Vegetables under glass & 22 & $(-21 \%)$ \\
Flowers (outside growth) & 39 & (NA) \\
Bulbs (always outside growth) & 39 & (NA) \\
\hline
\end{tabular}

sector. Peers are increasingly regarded as competitors and innovative ideas are no longer so easily shared. Some first cautious attempts are being made by the big firms to trade outside the (collective) auctions.

\section{Explaining the Success of the Westland Region}

\section{Micro Level}

At the firm level, the technological progress during the last decades has been stunning. The number of flowers per square meter has quadrupled during the last 30 years. The productivity growth can be mainly attributed to an ever increasing control of the growth process. In each successive technological innovation yet another variable was mastered. The original soil has been replaced by artificial soil, the water cycle has been closed, the influx of sunlight is controlled. ${ }^{14}$ and so is the level of humidity. Currently there are experiments with artificial lightning. ${ }^{15}$ In the near future it is expected that sensors will be used that can measure the growth process at the level of individual plants. This would enable real-time adjustment of the conditions in the greenhouse to the actual performance of plants. None of the more recent innovations would have been possible without the use of IT. An average greenhouse has about 500 variables that need to be controlled-most of these variables are interlinked and also have second order effects that need to be controlled. ${ }^{16}$

It is however not the use of (information) technology per se which gives the Westland its competitive edge. Porter is a long-time advocate of the strategic positioning of a business in a given industry (Porter 1979, 1998). The focus on the

\footnotetext{
14 This innovation is a direct outcome of the tight Dutch environmental regulation (Porter and van der Linde 1995). In order to reduce energy consumption in the horticulture industry the Dutch government made the use of sun blinds obligatory. Growers initially were reluctant to use the new technology since it reduced the influx of light and hence directly affected the yield. However, the technology turned out to be a blessing in disguise. By dynamically controlling the sun blinds the irregularity of the natural patterns of sunshine could be evened out. This has significantly increased rather than decreased yields. The latest process innovation is to directly feed highly localized weather forecasts into the computers that control the movement of the blinds (Meteoconsult, mimeo).

15 This is a rather energy-intensive method that might not be economically feasible at all—or only at a very large scale.

${ }^{16}$ For instance, too much or too frequent changes will slow down the growth of plants (in the words of one of the nurserymen we interviewed, "they get stressed"...) The special process computers that are needed to control the greenhouses are developed and produced by local Westland firms such as Priva (http://www.priva.nl).
} 
business environment is at the heart of his work. He does however, have a blind spot for the inherent qualities of a firm or cluster of firms, such as proclaimed by the resource-based approach. The core competency of a firm or cluster is the collective learning, especially how to co-ordinate diverse production skills and integrate multiple streams of technology (Prahalad and Hamel 1990, emphasis added). It is exactly this collective learning which has enabled a constant rapid spread of new ideas and innovation within the Westland cluster. The exchange of in-depth knowledge about businesses processes between peers has been one of the hallmarks of the region and is rooted in a very old tradition. The sharing of potentially strategic information with competitors might in the short run appear contra productive but makes sense at the longer run (Pfeffer 1994). Innovations are rarely individual achievements. Collaborating on new ideas upgrades the cluster as a whole and eventually pays off for all individual members. The use of ICT has just made the sharing of information easier. For instance, the logs of the process computers are centrally stored and meticulously studied to find optimal settings for the process computers. ${ }^{17}$

The remarkable openness of the cluster is not so much due to individual characteristics but rather to the constant growth of productivity in an ever expanding market. Under the present situation of overproduction and shrinking margins, growers are increasingly reluctant to cooperate and share potentially strategic information. In a sense, this is a perverse effect of the very success of the cluster. Because each subsequent major technological innovation seems to be more capitalintensive overall technological progress induces increases of scale. At the same time, the constant expansion of the market has now truly created a global market. The competition from countries with comparative advantages is on the rise. The only way Dutch nurseries can survive is to introduce yet another innovation at an even faster pace. This is a direct attack on the social fabric of the region. Family business are disappearing, the increases in scale lead to overproduction, lower margins, more competition and less openness. The share of family workers is rapidly going down and more than a $20 \%$ decrease was recorded over the 20002002 period. Eventually, in the Netherlands, only a few big nurseries might survive and ultimately they might relocate major parts of their production to tropical countries-not an unlikely scenario when these big firms are bought up by multinationals. Only the supporting functions (logistics, auctions, services) might remain vital and strong in The Netherlands. ${ }^{18}$

Meso Level

Although the Dutch flower cluster exports its products (usually within $24 \mathrm{~h}$ ) to every imaginable corner of the world, the production itself occurs on a relatively small

\footnotetext{
17 See, for instance, http://www.groeinet.nl.

18 Den Hertog et al. (2001) state that it remains to be seen whether the presence of an own primary production is a necessary precondition to maintain the nexus of the global logistical system in The Netherlands. They argue that at least some production should be done in The Netherlands in order to keep the knowledge up to standards.
} 


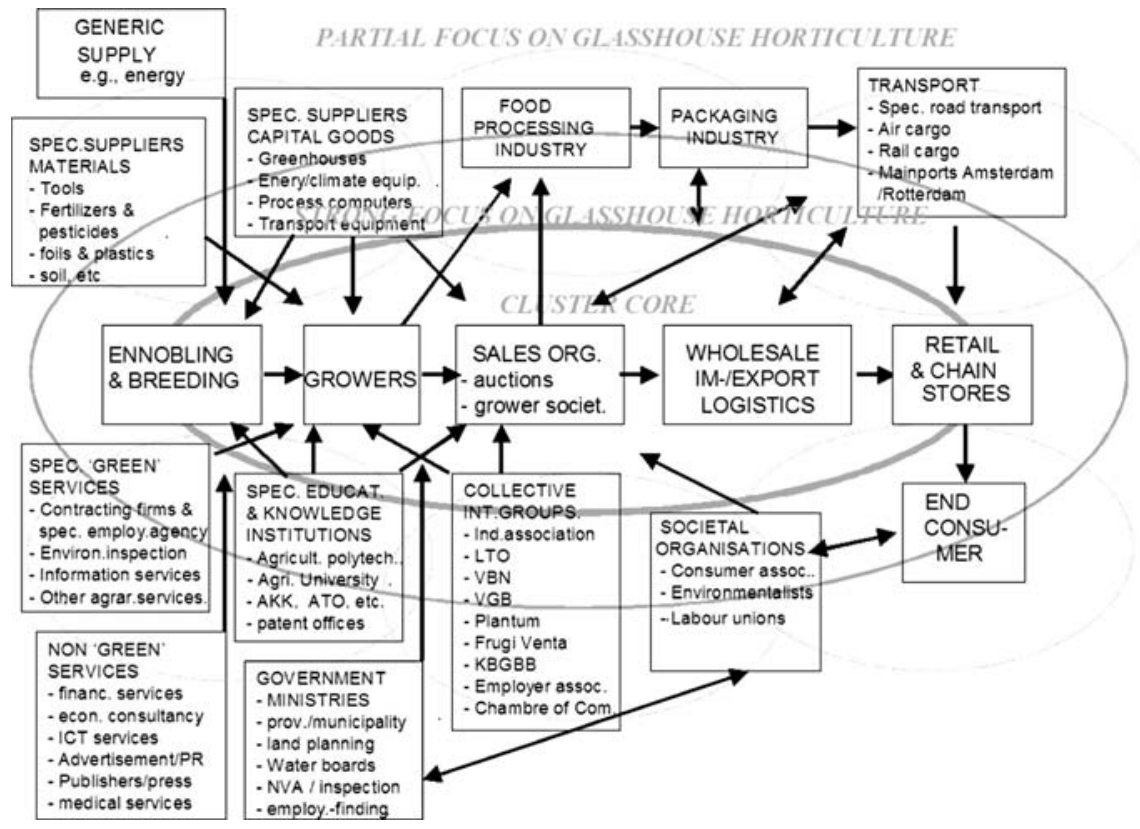

Fig. 1 The Dutch flower cluster at a glance

regional scale. Thus it combines the advantages of producing for a world market (a huge marketing area, experiencing world-class competition) with the advantages of a small industrial district (e.g., proximity, dense social networks). ${ }^{19}$ What makes the Westland cluster unique is its extreme degree of interwoven ness and the local presence of a great number of highly specialized related and supporting industries (e.g., firms specialized in transport and packaging of flowers, laboratories dedicated to horticulture, the auctions etc. ${ }^{20}$ ) - the fourth corner of Porter's diamond.

The biggest competitive advantage of the Westland cluster is the concentration of a very complete range of products and services (Fig. 1). At an early stage the cluster already reached a scale which enabled extreme specialisation (see, for instance, Jacobs and de Jong 1992). Of crucial importance is the tight coupling between production and trade-also in terms of physical proximity. Especially for cut flowers, freshness rules and time is everything. The time frame is in hours, not in days.

\footnotetext{
19 In this respect the Westland might not be much different from a typical industrial district. Within The Netherlands, the region is rather unique (the only comparable cluster may be the Dutch dairy industry). ${ }^{20}$ In the transport component, for instance, not only are there numerous local firms specialized in the transport of flowers but they are even further specialized in the transport of specific types of flowers. In the non "green" services, the local banks are completely tuned to the special financial needs of nurseries (which includes very attractive financial schemes for [re]starting of nurseries - the banks know it is safe business).
} 
The logistics chain is tightly integrated. The auctions-which are collectively owned by all growers ${ }^{21}$ - are the heart of the chain. Nurseries electronically send information on their flowers and plants to the auction in advance. ${ }^{22}$ Customers (exporters and wholesalers) can see what is on offer before the auction clock starts running. They can also pass this information on to all their customers in Europe and abroad. The 'Clock Supply Online' supply information system, which can be viewed by buying companies, enables customers to see which flowers and plants are to be auctioned the next day, and their quantities and numbers.

Transactions are settled in an extremely efficient way. In the Aalsmeer auction alone, every day 19 million flowers and 2 million plants are being sold-and the auction closes at 11:30. There are nearly 300 species of flower sold, each of which has a number of varieties. ${ }^{23}$ In addition to this, most flowers are available in different quality classes and stem lengths. By noon, all these flowers are on their way to their final destination, either by truck of airplane. Usually they arrive the same day at their destination. The auctions are in fact so efficient that flowers from abroad are being shipped to The Netherlands for the sole reason of being traded at the auctions.

A small but growing proportion of transactions is directly being closed between an exporter/wholesale trader and a client. ${ }^{24}$ Although such 'mediated' transactions formally bypass the auctions they usually still make use of the infrastructure of the auctions. This is because the logistical and financial system of the auctions is highly efficient. For instance, the auctions always settle financial transactions within a week, regardless whether the client has paid for the flowers or not. However, the rise (or rather: return) of the middlemen undermines the very existence of the auctions which were precisely founded as a collective stronghold of the nurseries against the

\footnotetext{
21 Bloemenveiling Aalsmeer (VBA) is a cooperative in the joint ownership of 3,500 member growers which was born as a typically Dutch reaction to the power of the middlemen. The members appoint a board of nine from among their ranks, all of whom are growers, to determine policy. A chairman, a vicechairman and a secretary are selected from this board. Management and the implementation of policy are in the hands of the three general management members (managing director, commercial director and operational director). The Supervisory Board provides policy recommendations and verification. Half of the members of this board are member growers while the other half are experts drawn from Dutch industry and university life. The 3,500 cooperative members are grouped into 15 regionally active sections, each with a section board. The section boards and cooperative management regularly gather during policy meetings. General meetings take place twice a year, to which all members are invited.

22 A standardized electronic consignment note is being used. A printout of the note is attached to the trailers with flowers. Specialized transport firms pick up the trailers from the nurseries (and drop empty ones for the next day) and deliver the flowers to the auctions.

23 For example, there are 300 gerberas, over 500 chrysanthemums and 400 different roses. The incredible variation in flowers is a result from the differentiation strategy that was been followed by most Dutch growers up to the early 1990s. After the shift in favourable market conditions (demand no longer exceeded supply) the increasing pressure on margins forced many growers to turn to a cost domination strategy.

24 One example is the wholesale trader Metz which directly delivers flowers from nurseries to its customers around Europe. Customers can place their orders via Metz' own electronic system IRIS (see http://www.metz.nl/en/index.html). The financial settlement is still via one of the auctions.
} 
middlemen. Hence the strict obligation for all members (the nursery men) to offer their products exclusively via the auction. The decision to also allow mediated transactions via the auction infrastructure (and even to be active on the mediation market-via MVA), hence to 'sleep with the enemy', seems to be dictated by rather pragmatic considerations: the acceptance of the rise of mediated transactions as a matter of fact and the attempt to keep that part of the trade at least partly under control. $^{25}$

Due to its sheer size and range of flowers it is nearly impossible to replicate the Dutch auctions elsewhere. They are truly a global nexus of demand and supply. In the Aalsmeer auction alone, over 6,000 growers world-wide supply flowers which are bought by over 1,100 wholesalers and exporters; the annual turnover is over 1.5 billion euro, including cut flowers, houseplants and garden plants (the service turnover, including packaging turnover and profits from tenancies and leases, is 158 million euro). Around 10,000 individuals work within the Bloemenveiling Aalsmeer complex (including those working for exporters, wholesaler's banks, transporters and other service providers). This can rise to 12,000 during peak periods such as St Valentine's Day or Mother's Day. So far there has been only one alternative which has succeeded to operate independently of the auctions: the Teleflower Auction (TFA). ${ }^{26}$ Yet it is still located in The Netherlands, at striking distance from the Aalsmeer auction and Schiphol Airport.

Market prospects for both Aalsmeer and Naaldwijk are good and a $45 \%$ increase in sales is expected in the next 10 years. The direct trade flows form a significant area for concern (MVA increase in Aalsmeer is in that sense a signal that the market demand not just auctions and low prices but also increasingly tailored relationships between producers and traiders), but with good commercial instruments and by offering professional services at competitive rates they will still be able to attract a broad and deep international supply, and this automatically represents purchase power. Dutch export of horticultural products has been increasing constantly in recent years: Russia, Denmark and Italy are the fastest growing export markets in EU (Table 3).

\section{A Synthesis of the Dutch Case}

The Competitive advantage of nations is one of the most influential books on development theory. At its publication in 1990 it has received an enormous interest in the press and media. That reception of the book in the academic community was much less warm not to say the least, up to a point where Davies and Ellis amended Grant's initial judgement from 'gloriously rich but hopelessly intractable' (Grant 1991, pp. 542-553) to 'hopelessly rich but gloriously wrong' (Davies and Ellis 2000, p. 1210).

\footnotetext{
25 Marketing \& Sales Aalsmeer (MVA) is the active sales organisation of the VBA. MVA helps to gear products to the wishes and needs of the market as accurately as possible, and provides expert advice in customised operations. MVA also provides customers with tailored supply information. In $200311 \%$ of cut flowers transactions (up from $9 \%$ in 2002 and $8 \%$ in 2001).

26 TFA is specialized in roses grown outside the Netherlands (especially Africa).
} 
Table 3 Dutch export of horticultural products (sales turnover million of euro)
Source: Dutch Floricultural Wholesale Board

\begin{tabular}{lrrrr}
\hline & 2001 & 2002 & 2003 & $\Delta \% 2003 / 2002$ \\
\hline Germany & 1,496 & 1,512 & 1,585 & 5 \\
UK & 652 & 729 & 741 & 2 \\
France & 594 & 606 & 649 & 7 \\
Italy & 257 & 281 & 317 & 13 \\
Belgium & 147 & 164 & 184 & 12 \\
Switzerland & 128 & 141 & 134 & -5 \\
Austria & 121 & 127 & 133 & 5 \\
Denmark & 99 & 107 & 123 & 15 \\
USA & 144 & 143 & 115 & -20 \\
Russia & 74 & 87 & 104 & 20 \\
Other countries & 600 & 671 & 678 & 1 \\
Total & 4,312 & 4,568 & 4,763 & 4 \\
\hline
\end{tabular}

The major point of criticism is that Porter's 'competitive advantages' are nothing new under the sun. It is merely a (faulty) popularisation of the well-established vast theoretical body of work on comparative advantages (Davies and Ellis 2000, p. 1199). For instance, on the one hand, classical comparative advantages are one of the corner stones of his diamond model (the 'factor conditions'). On the other hand, comparative disadvantages are an important stimulus for technological innovation, which is the primal driving force in Porter's model. Secondly, Porter mixes up two objects of analysis, the nation state and the firm. The fact that it is not clear at all what exactly defines a 'nation' or a 'home-based firm' renders his central thesis that the nation's prosperity depends upon that of its home base firms void of any meaning (Reich 1990, 1991). Thirdly, Porter's diamond model seems to be particularly flawed if applied to small, open trading economies (Davies and Ellis 2000, pp. 1203-1204).

Fourthly, all these comments are valid by there is more to it. The central thesis of The competitive advantage of nations is that successful companies are characterized by strong export figures, and that their success is based on a geographically concentrated 'diamond' in their home country. There is indeed little empirical evidence to support this claim, thus most of the critique seems to be justified. However, the Dutch case is one of the rare empirical examples which actually strongly confirms Porter's model-despite the fact that it is located in The Netherlands, a prime example of a small, open trading economy. The geographic concentration of the Westland region, with its dense local network of related and supporting industries, has made it the most successful flower exporting region in the world. Thus it is the strong home based diamond which seems to give the Westland its cutting edge-despite the apparent presence of comparative disadvantages (cold climate, lack of land, high labour costs).

Porter's model, however, misses three important points when it comes to the explanation of the exceptional success of the Dutch flower cluster. First and foremost, the model does not explain how the four determinants of the diamondfactor conditions, demand conditions, related and supporting industry, and firm 
strategy, structure and rivalry-combine to create self-reinforcing conditions in which a nations firm succeed internationally. Especially, the evolutionary stand of the model does not explain why factor conditions - comparative advantages-are sometimes drivers and sometimes obstacles (Davies and Ellis 2000, p. 1190). One of the key findings of the Dutch case is that comparative advantages and competitive advantages are not opposed but they actually reinforce each other.

One major legacy of the diamond is, in fact, a clear and sharp distinction in the debate between 'comparative advantages', based on cheap labour and climate, and 'competitive advantages', based on the diamond as a whole: 'According to the standard economic theory, factors of production-labour, land, natural resources, capital, infrastructure-will determine the flow of trade [..]. This doctrine, whose origins date back to Adam Smith and David Ricardo [..], is at best incomplete and at worst incorrect' (Porter 1990b, p. 78). So that the old Ricardian 'comparative advantages' are not really part of the diamond itself, because the diamond side called 'factor conditions' is related to the factors nations are able to create. Such a contrast was drawn clearly by Porter himself and its one of its main legacy: "broad distinctions are drawn between 'basic' factors like climate and unskilled labour and 'advanced' factors which have to be created, like computer scientist and communication infrastructures' (Davies and Ellis 2000, p. 1190).

The Dutch flower cluster shows that such a contrast may well be solved out. All eventual strong diamonds have to originate from comparative advantages. In the particular case of the Westland, these where the fertile lands behind the dunes. From the onset, these comparative advantages where accompanied by favourable demand conditions (nearby big cities that could be reached by waterways). Based on this good starting point, the Dutch growers could then introduce a new technological innovation (sun lounges from Belgium) to overcome the comparative disadvantage of a bleak climate. The sun lounges were later perfected into sophisticated greenhouses which where also a technological answer to the ever-increasing pressure on land use. Around the greenhouse industry, a vast and densely knit supporting industry (with a strong science and technology base) sprung up. The conquest of the world market was further supported by the exploitation of a hitherto unused comparative advantage-natural gas. More recently, yet another disadvantages - the stern environmental policy of the Dutch government - has pushed the growers even further into technological innovation-something akin the way the high degree of unionization pushed Italian car manufacturers to automate (O'Shaughnessy 1996, p. 19).

Neither comparative advantages nor competitive advantages alone can explain the worldwide success of the Westland region. The phenomenal success of the Westland can only be described as a constant leapfrogging between the two types of (dis)advantages - there is continuous interaction. The fact that Porter is silent on how this interaction occurs is because of his bias towards technological innovation. He therefore greatly underestimates the importance of social innovation - this is his second major omission. In the particular case of the Westland, the establishment of the cooperatives and the auctions where probably at least as important as the technological innovations. Eventually this resulted in a local culture that was very open and inducive to the diffusion of all kinds of technological innovations. Thus a 
major strength from the Westland region-its ability for collective learning - comes from within. This argument is much closer to the resource-based perspective and to the most recent cluster literature (Asheim et al. 2006) than to Porter's emphasis on external pressure. Related to this is Porter's bias towards local competition as a driver for innovation. Although there might have been competition between the Dutch growers it is not a Hobbesian 'war of all against all' - the foundation of the entire Porterian edifice (Aktouf et al. 2005, p 198). It could rather be characterised as a constructive process of mimesis.

Ironically, the constant stream of technological innovations-which are so much hailed by Porter, is now undermining the particular social fabric of the Westland region. Increases in scale-which are a direct consequence of the dominant high tech/high investment strategy — are quickly putting an end to the smaller family businesses. The gap between the front runners and the vast group of followers has strongly grown lately (Den Hertog and Kern 2007, p. 9). The big firms are leaving the cooperative auctions and go on their own. The open innovation culture is quickly eroding - exclusivity and the protection of intellectual property rights are on the rise (Den Hertog and Kern 2007, p. 12). Ultimately, the disappearance of mutual learning might lead to the collapse of the Westland cluster-one of Porter's last remaining diamonds.

However, the end of the diamond does not necessarily imply the end of the Dutch greeneries. Porter's third major omission is that he does not see that a firm can eventually do very well changing its original location. He distinguishes three successive stages in which the competitive advantages are upgraded. The first stage is factor-driven, the second investment driven, and the third innovation-driven (Yetton et al. 1992, p. 93). There is a logical linear order in this as it describes a dynamic process moving from a factor-based situation via a situation where technology is being used to further exploit the factor conditions to a situation where technological innovation has become a driver on its own and factor conditions are no longer relevant. The last (innovation-driven) stage seems to be the maximum situation. The subsequent 'wealth-driven' stage that Porter distinguishes is therefore inevitably one of drift and decline (Porter 1990a, b, p. 546). When the Westland remains to be locked into the high-tech/high investment strategy this might indeed be an accurate prediction.

There is however, an alternative strategy which is much more in line with the dynamic leapfrogging process between comparative and competitive advantages (Den Hertog and Kern 2007, p. 16). All strong diamonds do indeed originate from favourable factor conditions. This is the thesis of the comparative advantage paradigm. In the two following stages competitive advantages are the driving force. This is Porter's antithesis of competitive advantages. But this is not where it necessarily ends. In the fourth stage, comparative advantages and competitive advantages are combined by firms who leave their original home base and move to nations with better comparative advantages. They can do so because the competitive advantages are not only situated in the local homebase (Martin and Sunley 2003), the diamond of external pressures, but also and predominantly embodied in the skills and knowledge of the people (Aktouf et al. 2005, p. 189). This closes the loop. 
The factor-driven stage starts all over again, but due to the presence of peopleembodied competitive advantages this time on a higher level. ${ }^{27}$

\section{References}

Aktouf O, Chenoufi M, Holford D (2005) The false expectations of Michael Porter's strategic management framework. Problems Perspect Manage 4:181-200

Asheim B, Cooke P, Martin R (eds) (2006) Clusters and regional development; critical reflections and explorations. Routledge, London

Cooke P, Leydesdorff L (2006) Regional development in the knowledge-based economy: the construction of advantage. J Technol Transfer 31:5-15

Davies H, Ellis P (2000) Porter's competitive advantage of nations: time for the final judgement? J Manage Stud 37:1189-1214

De Groot N (2001) Het glastuinbouwcomplex in het 3e millenium (mimeo)

Den Hertog P, Alleblas J, Bongers F (2001) Het glas is halfvol, het glas is halfleeg: Clustermionitor Glastuinbouw. Dialogic/LEI, Utrecht/Den Haag

Den Hertog P, Kern S (2007) Innovatie in de glastuinbouw (mimeo)

Grant RM (1991) Porter's competitive advantage of nations: an assessment. Strategic Manage J 12:535548

Häikiö M (2002) Nokia: the inside story. FT/PrenticeHall

Jacobs D, de Jong MW (1992) Industrial clusters and the competitiveness of the Netherlands: empirical results and conceptual issues. De Econ 140:233-252

Langford CH, Wood JR, Ross T (2003) Origins and structure of the Calgary wireless cluster. In: Wolfe DA (ed) Clusters old and new: the transition to a knowledge economy in Canada's regions. School of Policy Studies, Kingston

Martin R, Sunley P (2003) Deconstructing clusters: chaotic concept or policy panacea? J Econ Geogr 3:5-36

Moore JF (1996) The death of competition: leadership \& strategy in the age of business ecosystems. HarperCollins, New York

O'Shaughnessy NJ (1996) Michael Porter's competitive advantage revisited. Manage Decis 34:12-20

Pfeffer J (1994) Competitive advantage through people. Calif Manage Rev 36:9-28

Porter ME (1979) How competitive forces shape strategy. Harvard Bus Rev 57:137-145

Porter ME (1990a) The competitive advantage of nations. London Free Press, London

Porter ME (1990b) The competitive advantage of nations. Harvard Bus Rev 68:73-93

Porter ME, van der Linde C (1995) Green and competitive: ending the stalemate. Harvard Bus Rev 73:120-134

Porter ME (1998) On competition. Harvard Business School Press, Boston

Porter ME (2000) Location, competition and economic development: local clusters in a global economy. Econ Dev Quart 14:15-34

Porter ME (2001) Strategy and the Internet. Harvard Bus Rev 79:63-78

Prahalad CK, Hamel G (1990) The core competence of the corporation. Harvard Bus Rev 68:79-93

Reich R (1990) Who is us? Harvard Bus Rev 68:53-64

Reich R (1991) Who is them? Harvard Bus Rev 69:77-88

Storper M (1993) Regional "worlds" of production: learning and innovation in technology districts of France, Italy and the USA. Reg Stud 27:433-456

Storper M (1995) The resurgence of regional economies, ten years later: the region as a nexus of untraded interdependencies. J Euro Urban Reg Stud 2:191-221

Storper M (1997) The regional world: territorial development in a global economy. Guilford Press, New York

\footnotetext{
27 The jump from antithesis to synthesis is not a trivial and easy one since it involves a genuine paradigm shift from labour substitution (the high-tech trajectory) to labour upgrading (Den Hertog and Kern 2007). It remains to be since to what extend the Westland cluster can make that transition and whether emigrating individual firms can survive on their own, isolated from the tightly knit original home base.
} 
Tallman S, Jenkins M, Henry N, Pinch S (2004) Knowledge, clusters and competitive advantage. Acad Manage Rev 29:258-271

Yetton P, Craig J, Davis J, Hilmer F (1992) Are diamonds' a country's best friend? A critique of Porter's theory of national competition as applied to Canada, New Zealand and Australia. Aust J Manage 17:89-120 